\title{
The Impact of Academic Supervision on Teacher Pedagogical Competence and Teacher Performance: The Role Moderating by Teacher Efficacy
}

\section{Sarlota Singerin ${ }^{*}$}

${ }^{1}$ Pattimura University, Ambon, Indonesia

\section{ART ICLE INFO}

Article history:

Received April 27, 2021

Revised April 28, 2021

Accepted July 02, 2021

Available online August 25, 2021

Kata Kunci:

Supervisi, Kompetensi Pedagogik, Kinerja, Efikasi Diri

Keywords:

Supervision, Pedagogic

Competence, Performance, SelfEfficacy

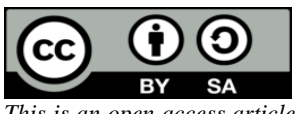

This is an open access article under the CC BY-SA license.

Copyright (C) 2021 by Author.

Published by Universitas Pendidikan Ganesha.

\section{A B S T R A C T}

The success of the performance shown by the teacher is influenced by the surrounding environment, one of which is the role of the principal as a school supervisor. In addition, the quality of teacher performance can also be caused by the teacher's self-efficacy. This study aims to determine the effect of academic supervision on pedagogic competence and performance moderated by teacher efficacy. This research is a quantitative research that aims to determine the causal relationship between variables. The population in this study were all elementary school teachers with a sample involving 100 teachers who were selected by simple random sampling technique. Data collection in this study used a questionnaire distributed through the Google Form. The data collected was then analyzed by researchers assisted by the Smart PLS application. The results show that academic supervision has an effect on pedagogic competence with $\mathrm{t}$ count $>$ t-table $(4.790>1.984)$ and a $\mathrm{P}$ value $<5 \%(0.000<0.05)$, academic supervision has an effect on teacher performance with $\mathrm{t}$-count $>\mathrm{t}$-table $(4.344>1.984)$ and a $\mathrm{P}$ value $<5 \%(0.000<0.05)$, Efficacy was not able to moderate the effect of academic supervision on pedagogic competence with $\mathrm{t}$-count $<\mathrm{t}$-table $(0.946<1.984)$ and $\mathrm{P}$ value $>5 \%$ alpha standard $(0.345>0.05)$. Self-efficacy is able to moderate the effect of academic supervision on teacher performance with $\mathrm{t}$-count $>\mathrm{t}$-table $(3.165>1.984)$ and a $\mathrm{P}$ value $<5 \%(0.032<0.05)$. Testing the moderating effect shows that efficacy is able to moderate the effect of supervision on teacher performance, while the pedagogical competence shows that efficacy has not been able to provide a significant moderating effect on pedagogic competence.

\section{INTRODUCTION}

The role of a teacher is very important in the world of education, in line with the challenges of global life, the roles and responsibilities of teachers in the future will be more complex (Darling-Hammond et al., 2017). Competence pedagogy is a must-have major for teachers to be able to create an effective and dynamic learning (Saleh, S. et al., 2019). As stated in the elaboration of article 28 paragraph 3 point (a) which explains that pedagogic competence is the ability to manage learning which includes understanding of students, planning and implementing learning, evaluating learning outcomes and developing students to actualize their various potentials. Quality of learning both is an indication of good pedagogical 
competence of teachers, experienced pedagogic competence can significantly affect the quality of eLearning (Sikki et al., 2013). In the learning process, the teacher's task should not only to teach to convey or transform knowledge, but also to develop the personality of their students in an integrated manner (Suciu \& Mata, 2011). Teachers are not only skilled in delivering teaching materials, but also skilled in developing students' personalities, character, and consciences (Hughes, 2012; Toropova et al., 2021). One of the efforts that can be done to overcome this problem is to increase pedagogical competence. Good pedagogical competence can be identified based on the teacher's ability to understand the principles of learning principles, learning theory to mastery teaching materials (Gervais, 2016).

Changes evolving era must also counter balanced with new programs that are relevant to the needs and demands of the curriculum. On the other hand, the change in curriculum has an impact on the difficulty of educators in determining appropriate learning activity scenarios, not to mention that the new curriculum brings changes from goals, methods, strategies that feel difficult to understand (Bowe et al., 2017). Some educators are known to have difficulties in applying the methods, strategies and evaluation of learning, several other educators feel difficulty facing learners in the millennial era which made it difficult to educators in doing learning program. In this increasing complex condition, it is necessary to have the support of all school components including the role of the principal as a supervisor (Carter \& Abawi, 2018; Hoppey \& McLeskey, 2013; Irvine et al., 2010; Valdivieso, 2020). One form of supervision related to the learning process is academic supervision. As a supervisor, in carrying out duties, there are several things that need to be developed for each teacher by the principal, including the personality of the teacher, continuous improvement on the profession, the learning process and mastery of subject matter. Some previous research revealed that academic supervision has a significant positive effect on pedagogical competence (Aswinda et al., 2019; Bafadal et al., 2019; A. Istiningsih et al., 2019; Porniadi et al., 2019; Saleh \& Arhas, 2019).

The principal must have a leadership spirit or school management skills (Lubguban, 2020; Wahyuddin, 2017). Teaching and learning activities can run well and smoothly, if all school members work to get joy and satisfaction at school (Hanley et al., 2020; Óskarsdóttir et al., 2020). For this reason, the principal must have the ability or skill as an educational developer and guide in realizing the maximum utilization of each person in carrying out his duties. In addition to functioning as managerial supervisors, the principal is also an academic supervisor. As an academic supervisor, the principal has an obligation to help teachers become professionals so that teachers can improve the quality of the learning process. Academic supervision activity is not an assessment of teacher performance, which only measures the quality of teachers in fulfilling their main tasks and functions for accreditation purposes. Academic supervision is a series of activities to help teachers develop their ability to manage the learning process for the achievement of learning objectives (Fauzan, 2020; Memah et al., 2019). Thus, in essence, academic supervision does not at all assess the performance of teachers in managing the learning process, but rather helps teachers to develop their professional skills.

Besides having an effect on pedagogic competence, academic supervision can also affect teacher performance. findings revealed that the intention of supervision has a positive effect on teacher performance (Arman et al., 2016; Fauzan, 2020; Hoque et al., 2020; Rathel et al., 2008; Sudarjat et al., 2015; Veloo et al., 2013). Teacher performance is an important element in education, besides that performance is a determinant of the level of education quality. Teacher performance is carried out by the teacher in carrying out the duties of a teacher as an educator. The quality of teacher performance determines the quality of educational outcomes because the teacher is the person who mostly interacts directly with students during the learning process. The success of the teacher's performance is influenced by the surrounding environment. Therefore, the surrounding environment, especially in this case, the school, such as the principal, must be able to motivate and empower teachers to create good performance and be able to play a role as a professional teacher in addition to the teacher himself who is able to improve the quality of his own work. Teacher performance is basically the performance or performance carried out by teachers in carrying out their duties as educators. The quality of teacher performance will greatly determine the quality of educational outcomes, because teachers are the party who has the most direct contact with students in the education / learning process in educational institutions / schools.

The main purpose of academic supervision is to improve the quality of learning, which ultimately hopes for student achievement (Erpidawati et al., 2019). Of course, this increase can not only be about one aspect, but all elements related to the learning process, including students themselves, teachers and other personnel, equipment, management, and the learning environment. A good principal is a principal who has leadership traits and behaviors that are able to create a good school climate and provide high job satisfaction for teachers or subordinates (McGeown, 1979; Velasco et al., 2012). The principal in his role as a leader must be able to direct others to do the tasks he wants and be fun for the teachers at work. A good leader is the principal is a leader figure who is ready to work intensively and is able to foster and 
guide teachers, and must always foster enthusiasm and motivation in order to create a harmonious relationship between the leader and those being led, thereby increasing the high quality of work so that it will be good work performance (McGeown, 1979). Those who are able to pay attention to the needs and goals of those who work for them (subordinates) are not focused on the power they have so that subordinates' job satisfaction is always fulfilled. Performance satisfaction and work performance are strongly influenced by one's self-efficacy. A person's competence can be realized by involving self-efficacy, namely the feeling that he/she is able to achieve his/her goals and mastery, and that he/she can acquire skills and overcome obstacles(Lee \& Tsai, 2010; Letarte et al., 2010), as well as being associated with the hope of success. This self-efficacy affects a teacher's self-confidence and job satisfaction and enthusiasm for achievement. A teacher with low self-efficacy has a weak belief in the ability to achieve and the skills to deal with all situations, especially when dealing with some forms of adversity and failure. A teacher who has high self-efficacy is expected to be able to carry out his duties and responsibilities well (Santrock, 2012).

Previous study suggest that the condition of low self-efficacy teacher could be influenced by several factors (Wahyuni \& Setiyani, 2017). Teachers who carry out their roles well are characterized by: pedagogical skills, namely the ability to teach, have adequate knowledge, have a professional attitude, are able to choose and create and use media, are able to develop curriculum dynamics and provide good examples and role models. Achieving educational goals in schools requires a role for a teacher, one of which is the readiness of the teacher to teach. With the increasing pressure for education reform in this country, quality teaching and teachers are hot issues that must be addressed wisely. Teachers and schools are required to meet educational standards. More specifically, in the context of education and schooling in Indonesia. One of the teacher qualities that is interesting to study in an effort to increase the effectiveness of teaching is self-efficacy. Teachers' self-efficacy is a special phenomenon that can be seen as one of the contributors to the process of learning and effective teaching. Previous study found that a teacher's selfefficacy can significantly influence pedagogical competence (Barni et al., 2019; Holzberger et al., 2013; Khanshan \& Yousefi, 2020). In addition, self-efficacy can improve individual performance (Jyoti \& Sharma, 2017; Mazzetti et al., 2020), this result is supported by findings, where self-efficacy is able to influence teacher performance (Kurt et al., 2014; Rodríguez et al., 2015). This study aims to determine the effect of academic supervision on pedagogic competence and performance moderated by teacher efficacy.

\section{METHOD}

The research approach used in this study is a quantitative approach. Quantitative research aims to examine the effect of digital transformation, marketing strategy, business size on competitive advantage and firm performance moderating by financial literacy in small medium enterprises in Indonesia. The population in this study were all elementary school teachers in North Maluku with a sample involving 100 teachers were selected by simple random sampling. The data in this study were collected through a questionnaire distributed with Google Form for further analysis using the Smart PLS application. The stages of data analysis in this study shown in Table 1.

Table 1. PLS Test Criteria

\begin{tabular}{|c|c|}
\hline Criteria & Explanation \\
\hline \multicolumn{2}{|l|}{ Outer Model Analysis } \\
\hline Outer Loading & $\begin{array}{l}\text { The outer loading score generates data for testing convergent } \\
\text { validity }\end{array}$ \\
\hline Construct Validity and Reliability & $\begin{array}{l}\text { Construct validity and reliability produce Discriminant Validity } \\
\text { data which is useful for validity testing and Composite } \\
\text { reliability which produces Cronbach Alpha scores for reliability } \\
\text { testing }\end{array}$ \\
\hline R2 & $\begin{array}{l}\text { The R2 test produces a score of R square and R Square } \\
\text { Adjusted to test the percentage of the effect of endogenous } \\
\text { variables on exogenous variables }\end{array}$ \\
\hline \multicolumn{2}{|l|}{ Inner Model Analysis } \\
\hline Path Coefficients & $\begin{array}{l}\text { Path Coefficients produce P-Values and T statistics scores that } \\
\text { are useful for hypothesis testing }\end{array}$ \\
\hline Specific Indirect Effect & $\begin{array}{l}\text { Specific indirect effects generate P-Values and T-statistical } \\
\text { scores that are useful for testing the indirect hypothesis }\end{array}$ \\
\hline
\end{tabular}


Analysis of the outer model The analysis of the outer model is carried out to ensure that the measurement used is feasible to be used as a measurement (valid and reliable). In the analysis of this model, it specifies the relationship between latent variables and their indicators. Outer model analysis can be seen from several indicators: (a) convergent Validity is an indicator that is assessed based on the correlation between the item score/component score with the construct score, which can be seen from the standardized loading factor which describes the magnitude of the correlation between each measurement item (indicator) and its construct. Individual reflexive measures are said to be high if the correlation is > 0.7; (b) discriminant Validity is a measurement model with reflexive indicators assessed based on the cross loading of measurements with constructs. discriminant validity, which is to compare the value of the square root of average variance extracted (AVE); (c) Composite reliability is an indicator to measure a construct that can be seen in the view of latent variable coefficients. In this measurement, if the value achieved is $>0.70$, it can be said that the construct has high reliability. (d) Cronbach's Alpha is a reliability test conducted to strengthen the results of composite reliability. A variable can be declared reliable if it has Cronbach's alpha value $>0.7$. (e) Changes in the value of the R-square can be used to assess the effect of certain independent latent variables on the dependent latent variable whether it has a substantive effect. Inner Model Analysis or commonly referred to as Structural Model is used to predict causal relationships between variables tested in the model. In testing the hypothesis, it can be seen from the value of t-statistics and probability values. To test the hypothesis by using statistical values, for alpha $5 \%$ the t-statistic value used is 1.96 . So the criteria for acceptance/rejection of the hypothesis are that Ha is accepted and $\mathrm{HO}$ is rejected when the t-statistic $>1.96$. To reject/accept the hypothesis using probability then Ha is accepted if the p value $<0.05$.

\section{RESULT AND DISCUSSION}

\section{Result}

\section{Evaluation of the Measurement Model (Outer Model)}

Evaluation of the outer model of the study is carried out by paying attention to the four criteria for measuring the outer model, the four criteria are Convergent Validity, Discriminant Validity, Composite Reliability and Cronbach Alpha. Convergent validity of the measurement model with some reflexive indicators can be seen from the correlation between the scores of items / indicators with a score construct. Individual indicators are considered reliable if they have a correlation value above 0.70 . However, at the research stage of the scale development, loading 0.50 to 0.60 is still acceptable (Ghozali, 2013). Based on the result for outer loading, all indicators have a loading above 0.50. Based on the measurement results of outer loading on the reflective indicator, it is known that all research indicators have met the criteria to be used as a variable measurement indicator because it has an outer loading value greater than 0.7 (outer loading $>0.7$ ). The data above shows that there is no variable indicator whose outer loading value is below 0.7 , so that all indicators are declared eligible or valid for research use and can be used for further analysis. In this study, researchers used 2 types of reliability tests, namely the Cronbach Alpha test and the Composite Reliability test. Cronbach Alpha measures the lowest value (lower bound) reliability. The data is declared good if the data has a Cronbach alpha value> 0.6. Meanwhile, composite reliability measures the actual reliability value of a variable. The data is declared to have high reliability if it has a composite reliability score $>0.7$. Based on the calculations, it was found that all items of the instrument were reliable with all variables having a Cronbach Alpha score $>0.6$ and Composite Reliability $>0.7$.

Table 2. Reliability Test

\begin{tabular}{llll}
\hline Variable & Cronbach Alpha & Composite Reliability & Information \\
\hline Academic Supervision (X) & 0.939 & 0.946 & Reliable \\
Competence (Y1) & 0.936 & 0.943 & Reliable \\
Performance (Y2) & 0.913 & 0.926 & Reliable \\
Efficacy (M) & 0.885 & 0.908 & Reliable \\
Moderating Effect (Y1) & 1,000 & 1,000 & Reliable \\
Moderating Effect (Y2) & 1,000 & 1,000 & Reliable \\
\hline
\end{tabular}

\section{Measurements The coefficient of determination (R)}

Coefficient determination (R-Square) is used in measuring how much the endogenous variable is influenced by other variables. Based on the data analysis carried out through the use of the SmartPLS program, the R-Square value was obtained as shown in the following table: 
Table 3. $\mathrm{R}^{2}$ value

\begin{tabular}{lccc}
\hline & R Square & R Square Adjusted & \\
\hline Performance (Y2) & 0.318 & 0.297 \\
Competence (Y1) & 0.678 & 0.668 \\
\hline
\end{tabular}

Based on the R Square value in the Pedagogic Competence model (Y1), the R Square value is 0.678. These results indicate that the Supervision variable is able to explain the Pedagogic Competence (Y1) variable of $67.8 \%$ while the remaining $32.2 \%$ is explained by variables not included in the research model. In the second equation, the Quality of Performance (Y2), the Square value is 0.318. These results indicate that the Supervision variable is able to explain the Quality Performance variable (Y2) of $31.8 \%$ while the rest is $68.2 \%$ explained by variables not included in the research model.

\section{Evaluation of the Structural Model (Inner Model)}

Based on the data processing that has been done, the results can be used to answer the hypothesis in this study. Hypothesis testing in this study was carried out by looking at the T-Statistics value and the P-Values value. The research hypothesis can be stated as accepted if the P-Values value $<0.05$. The following are the results of hypothesis testing obtained in this study through the inner model:

Table 9. Hypothesis Results

\begin{tabular}{lccccc}
\hline & $\begin{array}{l}\text { Original } \\
\text { Sample } \\
\text { (O) }\end{array}$ & $\begin{array}{l}\text { Sample } \\
\text { Mean } \\
\text { (M) }\end{array}$ & $\begin{array}{l}\text { Standard } \\
\text { Deviation } \\
\text { (STDEV) }\end{array}$ & T Statistics & P Values \\
\hline Efficacy (M) -> Performance (Y2) & -0.077 & -0.067 & 0.157 & 0.491 & 0.623 \\
Efficacy (M) -> Competence (Y1) & 0.360 & 0.376 & 0.114 & 3.165 & 0.002 \\
Moderating Effect Y1 -> Competence & 0.024 & 0.023 & 0.025 & 0.946 & 0.345 \\
(Y1) & & & & & \\
Moderating Effect Y2 -> Performance & 0.112 & 0.099 & 0.056 & 1,991 & 0.047 \\
(Y2) & & & & & \\
Supervision (X) -> Performance (Y2) & 0.643 & 0.653 & 0.148 & 4,344 & 0.000 \\
Supervision (X) -> Competence (Y1) & 0.516 & 0.507 & 0.108 & 4,790 & 0.000 \\
\hline
\end{tabular}

\section{Discussion}

The Effect of Academic Supervision on Pedagogic Competence

Hypothesis testing results show the influence of Academic Supervision of the Pedagogical Competence has a value of 0 . The path coefficient 516 and has a T-score statistics for 4790 and the value of $\mathrm{P}$-Value of 0000 . The statistical $\mathrm{T}$ value is greater than the $\mathrm{T}$ table $(4.790>1.984)$ and the $\mathrm{P}$ value is 0.000 or less than the $5 \%$ alpha standard $(0.000<0.05)$ indicating that there is a significant effect of Academic Supervision on Teacher Pedagogical Competence. In other words, the better Academic Supervision is able to improve Teacher Pedagogic Competence or the first hypothesis (H1) is accepted. These results at the same time support the findings which states that academic supervision has a significant positive effect on pedagogical competence (Aswinda et al., 2019; Bafadal et al., 2019; E. Istiningsih et al., 2020; Porniadi et al., 2019; Saleh \& Arhas, 2019). Pedagogic Competence is the ability to manage student learning, which includes understanding students, designing and implementing learning, evaluating learning outcomes, and developing students to actualize their various potentials (Habibullah, 2012). With the qualified academic supervision will be increased pedagogical competence of teachers, as well as with the academic supervision is expected to develop the resources owned by the teachers in these schools (Keller et al., 2017). The results of the study are in line with the results of research which suggests that academic supervision can improve teacher pedagogical competence (Mujiono, 2020). The results of the other study also concluded that academic supervision has a positive and significant relationship to pedagogical competence (Gess-Newsome et al., 2019).

\section{The Effect of Academic Supervision on the Quality of Performance}

Hypothesis testing results show the influence of the Academic Performance Quality Supervision has path coefficient value of 0.643 and has a T-score statistics for 4344 and the value of P-Value of 0000 . The statistical $\mathrm{T}$ value is greater than the $\mathrm{T}$ table $(4.344>1.984)$ and the $\mathrm{P}$ value is 0.000 or less than the $5 \%$ alpha standard $(0.000<0.05)$, indicating that there is a significant effect of Academic Supervision on the Quality of Teacher Performance. In other words, the better Academic Supervision is able to improve the Quality of Teacher Performance or the Second Hypothesis (H2) is accepted. Performance is the level of 
success of a person or group of people in carrying out their duties and responsibilities as well as the ability to achieve the goals and standards that have been set (Andriani et al., 2018). Some previous study states that academic supervision can have an impact on teacher performance. Supervision carried out by school principals to teachers is carried out regularly and on a scheduled basis in the hope that teachers are able to improve the learning process carried out (Arman et al., 2016; Fauzan, 2020; Hoque et al., 2020; Rathel et al., 2008; Sudarjat et al., 2015; Veloo et al., 2013).

\section{The Role of Moderation Efficacy in the Relationship between Academic Supervision and Pedagogic Competence}

The results of hypothesis testing show that Efficacy can moderate the positive supervision of pedagogic competence. The path coefficient value is 0.024 and has a statistical T value of 0.946 and a Pvalue of 0.032 . The statistical $\mathrm{T}$ value is smaller than the $\mathrm{T}$ table $(0.946<1.984)$ and the $\mathrm{P}$ value is 0.345 or greater than the $5 \%$ alpha standard $(0.345>0.05)$ shows that the efficacy of being able does not have a moderating effect on academic supervision of pedagogic competence. These results refute the findings which states that self-efficacy can have an influence on academic supervision and teacher pedagogical competence (Barni et al., 2019; Holzberger et al., 2013; Khanshan \& Yousefi, 2020; Wahyuni \& Setiyani, 2017).

\section{The Role of Moderation Efficacy in the Relationship between Academic Supervision and Performance Quality}

The results of hypothesis testing show that Efficacy is not able to moderate the supervision of the quality of performance. The path coefficient value is 0.360 and has a statistical T value of 3.165 and a Pvalue of 0.002 . Rated $T$ statistic is more substantial than the $T$ table $(3.165>1.984)$ and the value of the $P$ value equal to 0.002 or more smaller than the standard alpha $5 \%(0.032>0.05)$ showed efficacy was able to provide academic supervision moderating effect on the quality of performance. Teacher performance is the result of an assessment of the process and work results achieved by the teacher in carrying out their duties. The performance of a teacher is very much supported by self-efficacy because teachers who have high self-efficacy have a tendency to be able to make decisions about class management, organize a series of lessons, teach, motivate students to learn and communicate with students on an ongoing basis (Robbins \& Judge, 2013). Effective to support activities at school in order to achieve educational goals. The results of this study support the results of research which states that self-efficacy has a positive effect on teacher performance (Al-rahmi, 2013; Cherian \& Jacob, 2013; Kurt et al., 2014; Mcdougall \& Kang, 2003).

\section{CONCLUSION}

Based on the research results, academic supervision using a collaborative approach is able to have a positive and significant impact on the pedagogic competence of teachers. In addition, supervision also affects the quality of performance. Teacher efficacy is able to moderate the influence of supervision on teacher performance, and moderate the influence of academic supervision on pedagogic competence. For other researchers who want to do the same research, they can conduct research on different samples with more varied variables.

\section{REFERENCES}

Al-rahmi, W. M. (2013). The Impact of Social Media Use on Academic Performance among University Students: A Pilot Study. Journal of Information Systems Research and Innovation, 4(12), 1-10. http://seminar.utmspace.edu.my/jisri/.

Andriani, S., Kesumawati, N., \& Kristiawan, M. (2018). The Influence of the Transformational Leadership and Work Motivation on Teachers Performance. International Journal of Scientific and Technology Research, 7(7), 19-29.

Arman, Thalib, S. B., \& Manda, D. (2016). The Effect of School Supervisors Competence and School Principals Competence on Work Motivation and Performance of Junior High School Teachers in Maros Regency, Indonesia. International Journal of Environmental and Science Education, 11(15), 7309-7317. https://core.ac.uk/download/pdf/97978208.pdf .

Aswinda, A., Siraj, A., \& Saprin, S. (2019). Effect of Principal Supervision on Teacher Pedagogic Competencies. Jurnal Ilmiah Ilmu Administrasi Publik, 9(1), 95-100. https://doi.org/10.26858/jiap.v9i1.9331. 
Bafadal, I., Supriyanto, A., \& Arifin, I. (2019). Artistic Supervision Model Development for Improved Pedagogic Competence of Primary School Teachers. Elementary Education Online, 18(3), 12601286. https://doi.org/10.17051/ilkonline.2019.612140.

Barni, D., Danioni, F., \& Benevene, P. (2019). Teachers' Self-Efficacy: The Role of Personal Values and Motivations for Teaching. Frontiers in Psychology, 10, 1645. https://doi.org/10.3389/fpsyg.2019.01645.

Bowe, R., Ball, S. J., \& Gold, A. (2017). Reforming Education and Changing Schools: Case Studies in Policy Sociology. Routledge. https://doi.org/10.4324/9781315412122.

Carter, S., \& Abawi, L.-A. (2018). Leadership, Inclusion, and Quality Education for All. Australasian Journal of Special and Inclusive Education, 42(01). https://doi.org/10.1017/jsi.2018.5.

Cherian, J., \& Jacob, J. (2013). Impact of Self Efficacy on Motivation and Performance of Employees. International Journal of Business and Management, 8(14), 80. https://doi.org/10.5539/ijbm.v8n14p80.

Darling-Hammond, L., Hyer, M. E., \& Gardner, M. (2017). Effective Teacher Professional Development. Learning Policy Institute.

Erpidawati, E., Gistituati, N., Marsidin, S., \& Yahya, Y. (2019). The Development of the Academic Supervision Model Basic School Supervisor. 1st International Conference on Innovation in Education (ICoIE 2018), 19-22. https://doi.org/10.2991/icoie-18.2019.5.

Fauzan, A. (2020). The Effect of Academic Supervision, School Leadership, Organizational Culture, and Achievement Motivation on Teachers' Performance at Junior High Schools. 2nd International Conference Innovation in Education (ICoIE 2020), 177-180. https: //doi.org/10.2991/assehr.k.201209.214.

Gervais, J. (2016). The Operational Definition of Competency-Based Education. The Journal of CompetencyBased Education, 1(2), 98-106. https://doi.org/10.1002/cbe2.1011.

Gess-Newsome, J., Taylor, J. A., Carlson, J., Gardner, A. L., Wilson, C. D., \& Stuhlsatz, M. A. M. (2019). Teacher Pedagogical Content Knowledge, Practice, and Student Achievement. International Journal of Science Education, 41(7), 944-963. https://doi.org/10.1080/09500693.2016.1265158.

Ghozali, I. (2013). Multivariate Analysis Application with IBM and SPSS Programs. Diponegoro University Publishing Agency.

Habibullah, A. (2012). Kompetensi Pedagogik Guru [Teacher's Pedagogic Competence]. EDUKASI: Jurnal Penelitian Pendidikan Agama dan Keagamaan, 10(03), 169. https://doi.org/10.32729/edukasi.v10i3.169.

Hanley, T., Winter, L. A., \& Burrell, K. (2020). Supporting Emotional Well-Being in Schools in the Context of Austerity: An Ecologically Informed Humanistic Perspective. British Journal of Educational Psychology, 90(1). https://doi.org/10.1111/bjep.12275.

Holzberger, D., Philipp, A., \& Kunter, M. (2013). How Teachers' Self-Efficacy is Related to Instructional Quality: A Longitudinal Analysis. Journal of Educational Psychology, 105(3), 774. https://doi.org/10.1037/a0032198.

Hoppey, D., \& McLeskey, J. (2013). A Case Study of Principal Leadership in an Effective Inclusive School. Journal of Special Education, 46(4). https://doi.org/10.1177/0022466910390507.

Hoque, K. E., Bt Kenayathulla, H. B., Subramaniam, M. V., \& Islam, R. (2020). Relationships Between Supervision and Teachers' Performance and Attitude in Secondary Schools in Malaysia. SAGE Open, 10(2). https://doi.org/10.1177/2158244020925501.

Hughes, G. D. (2012). Teacher Retention: Teacher Characteristics, School Characteristics, Organizational Characteristics, and Teacher Efficacy. Journal of Educational Research, 105(4). https://doi.org/10.1080/00220671.2011.584922.

Irvine, A., Lupart, J., Loreman, T., \& McGhie-Richmond, D. (2010). Educational Leadership to Create Authentic Inclusive Schools: The Experiences of Principals in a Canadian Rural School District. Exceptionality Education International, 20(2). https://doi.org/10.5206/eei.v20i2.7664.

Istiningsih, A., Mawardi, M., \& Intan Permata, H. K. (2019). Peningkatan Keterampilan Berpikir Kreatif melalui Penerapan Model Pembelajaran Mind Mapping. Edukasi: Jurnal Penelitian dan Artikel Pendidikan, 11(1). https://doi.org/10.31603/edukasi.v11i1.2676.

Istiningsih, E., Suyatno, \& Widodo. (2020). Academic Supervision to Improve Teachers' Readiness in Utilizing Information and Communication Technology in Vocational High Schools. Universal Journal of Educational Research, 8(10), 4365-4373. https://doi.org/10.13189/ujer.2020.081002.

Jyoti, J., \& Sharma, P. (2017). Empirical Investigation of a Moderating and Mediating Variable in Between Mentoring and Job Performance: A Structural Model. Revista de Psicología Del Trabajo y de Las Organizaciones, 33(1), 55-67. https://doi.org/10.1016/j.rpto.2017.01.002. 
Keller, M. M., Neumann, K., \& Fischer, H. E. (2017). The Impact of Physics Teachers' Pedagogical Content Knowledge and Motivation on Students' Achievement and Interest. Journal of Research in Science Teaching, 54(5), 586-614. https://doi.org/10.1002/tea.21378.

Khanshan, S. K., \& Yousefi, M. H. (2020). The Relationship Between Self-Efficacy and Instructional Practice of In-Service Soft Disciplines, Hard Disciplines, and EFL Teachers. Asian-Pacific Journal of Second and Foreign Language Education, 5(1), 1-20. https://doi.org/10.1186/s40862-020-0080-8.

Kurt, H., Güngör, F., \& Ekici, G. (2014). The Relationship among Teacher Efficacy, Efficacy Regarding Teaching, and Responsibility for Student Achievement. Procedia - Social and Behavioral Sciences, 116, 802-807. https://doi.org/10.1016/j.sbspro.2014.01.301.

Lee, M. H., \& Tsai, C. C. (2010). Exploring Teachers' Perceived Self Efficacy and Technological Pedagogical Content Knowledge with Respect to Educational Use of the World Wide Web. Instructional Science, 38(1), 1-21. https://doi.org/10.1007/s11251-008-9075-4.

Letarte, M. J., Normandeau, S., \& Allard, J. (2010). Effectiveness of a Parent Training Program "Incredible Years" in a Child Protection Service. Child Abuse and Neglect, 34(4), 253-261. https://doi.org/10.1016/j.chiabu.2009.06.003.

Lubguban, M. G. B. (2020). Leadership Proficiency and Emotional Competence of Women School Administrators. Journal of Critical Reviews, 7(11). https://doi.org/10.31838/jcr.07.11.47.

Mazzetti, G., Paolucci, A., Guglielmi, D., \& Vannini, I. (2020). The Impact of Learning Strategies and Future Orientation on Academic Success: The Moderating Role of Academic Self-Efficacy among Italian $\begin{array}{lllll}\text { Undergraduate Students. } & \text { Education }\end{array}$ https://doi.org/10.3390/educsci10050134.

Mcdougall, G., \& Kang, J. (2003). Memory Self-Efficacy and Memory Performance in Older Males. International Journal of Men's Health, 2(2), 131. https://doi.org/10.3149/jmh.0202.131.

McGeown, V. (1979). School Innovativeness as Process and Product. British Educational Research Journal, 5(2). https://doi.org/10.1080/0141192790050208.

Memah, M. M., Lengkong, J. S. ., \& Krowin, M. (2019). The Effect of Academic Supervision and Teacher Participation in Teacher Work Group to Teachers Performance Catholic Religion Education on North Sulawesi Province - Indonesia. Journal of Education and Practice, 10(15).

Mujiono, H. (2020). Supervisi Akademik Meningkatkan Kompetensi Pedagogik Guru. Jurnal Dinamika Manajemen Pendidikan, 4(2), 113-121. https://doi.org/10.26740/jdmp.v4n2.p113-121.

Óskarsdóttir, E., Donnelly, V., Turner-Cmuchal, M., \& Florian, L. (2020). Inclusive School Leaders - Their Role in Raising the Achievement of All Learners. Journal of Educational Administration, 58(5). https://doi.org/10.1108/JEA-10-2019-0190.

Porniadi, F., Kardoyo, K., \& Yanto, H. (2019). The Pedagogical Competence Predict from Academic Supervision, Kompentation and Work Motivation. Educational Management, 8(1), 80-87. https://journal.unnes.ac.id/sju/index.php/eduman/article/view/26603.

Rathel, J. M., Drasgow, E., \& Christle, C. C. (2008). Effects of Supervisor Performance Feedback on Increasing Preservice Teachers' Positive Communication Behaviors with Students with Emotional and Behavioral Disorders. Journal of Emotional and Behavioral Disorders, 16(2), 67-77. https: //doi.org/10.1177/1063426607312537.

Robbins, S. P., \& Judge, T. A. (2013). Organizational Behavior (15th ed.). Pearson Education Inc.

Rodríguez, S., Regueiro, B., Blas, R., Valle, A., Piñeiro, I., \& Cerezo, R. (2015). Teacher Self-Efficacy and Its Relationship with Students' Affective and Motivational Variables in Higher Education. European Journal of Education and Psychology, 7(2), 107-120. https://doi.org/10.30552/ejep.v7i2.106.

Saleh, S., Arhas, S. H., Haerul, H., \& Nasaruddin, N. (2019). Utilization of Learning Media in Digital Simulation Subjects. Jurnal Office, 4(2), 79-90. https://doi.org/10.26858/jo.v4i2.9806.

Saleh, S., \& Arhas, S. (2019). The Effect of School Head Academic Supervision on Pedagogic Capability of Basic School Teachers in Manggala District Kota Makassar. In International Conference on Social Science 2019 (ICSS 2019), 84-86. https://doi.org/10.2991/icss-19.2019.233.

Santrock. (2012). Life Span Development (13th ed.). Erlangga.

Sikki, E. A. A., Rahman, A., Hamra, A., \& Noni, N. (2013). The Competence of Primary School English Teachers in Indonesia. Journal of Education and Practice, 4(11), 139-145. https: //core.ac.uk/download/pdf/234634396.pdf.

Suciu, A. I., \& Mata, L. (2011). Pedagogical Competences - The Key to Efficient Education. International $\begin{array}{lllll}\text { Online Journal of } & \text { Sducational }\end{array}$ https://www.acarindex.com/dosyalar/makale/acarindex-1423904375.pdf.

Sudarjat, J., Abdullah, T., \& Sunaryo, W. (2015). Supervision, Leadership, and Working Motivation to Teachers' Performance. International Journal of Managerial Studies and Research (IJMSR), 3(6), 146-152. https://repository.unpak.ac.id/tukangna/repo/file/files-20210118101022.pdf. 
Toropova, A., Myrberg, E., \& Johansson, S. (2021). Teacher Job Satisfaction: The Importance of School Working Conditions and Teacher Characteristics. Educational Review, 73(1). https://doi.org/10.1080/00131911.2019.1705247.

Valdivieso, P. (2020). School Leaders and Inclusive Education in Peru: A Case Study of Principal Leadership in an Effective Inclusive School. International Journal of Innovative Business Strategies, 6(2). https://doi.org/10.20533/ijibs.2046.3626.2020.0058.

Velasco, I., Edmonson, S., \& Slate, J. R. (2012). Principal Leadership Behaviors and School Climate: A Conceptual Analysis. Journal of Education Research, 6(3).

Veloo, A., Komuji, M. M. A., \& Khalid, R. (2013). The Effects of Clinical Supervision on the Teaching Performance of Secondary School Teachers. Procedia - Social and Behavioral Sciences, 93(2002), 35-39. https://doi.org/10.1016/j.sbspro.2013.09.148.

Wahyuddin, W. (2017). Headmaster Leadership and Teacher Competence in Increasing Student Achievement in School. International Education Studies, 10(3), 215. https://doi.org/10.5539/ies.v10n3p215.

Wahyuni, D., \& Setiyani, R. (2017). Pengaruh Persepsi Profesi Guru, Lingkungan Keluarga, Efikasi Diri terhadap Minat Menjadi Guru. Economic Education Analysis Journal, 6(3)(3), 669-683. https://journal.unnes.ac.id/sju/index.php/eeaj/article/view/20279. 